\title{
Living kidney donation and masked nationalism in Israel
}

\section{MIRAN EPSTEIN}

\begin{abstract}
This paper draws attention to a current trend of masked conditional-nationalist living kidney donation in Israel, to which the local transplant system has been turning a blind eye. The paper seeks to make the international transplant and bioethics communities aware of this disturbing trend. It also explains why it is wrong and suggests how to tackle it. Finally, it calls on the Israeli system to bring the practice to a halt for the benefit of all parties involved.
\end{abstract}

\section{Introduction}

In a better world, all organ donations would be unconditional, made to the global pool with no strings attached. Further, the organs would be allocated strictly on the basis of need. Economic considerations, social standing, class, race, ethnicity, faith, gender, nationality, age, reciprocity, friendship and even kinship would play no role in the decision-making process. Social solidarity would be the sole driver, means and end of the transplant enterprise.

Things are different in our world. The vast majority of living donations are conditional. In many cases, the system goes along with the donor's demands. However, even when the donor makes none, as is typically the case with deceased donation, the allocation system often sets its own conditions. Priority to local patients over aliens (also called the principle of self-sufficiency) and to those willing to donate to the organ pool over "free riders" are frequently cited examples (1:p5b;2).

Whether from the deceased or the living, conditional organ donation takes two general forms. First, it can be directed to a related or unrelated individual. In this case, it would be ethically acceptable and effectively binding, subject to certain terms and conditions. Second, it can be directed to or withheld from certain groups or types of people. This form of conditional donation is often sweepingly referred to favourably as socially directed donation (3). In the following, I will use the term sectarian donation, which I believe is more appropriate, accurate and informative.

Author: Miran Epstein (m.epstein@qmul.ac.uk), Reader in Medical Ethics, Centre for Primary Care and Public Health, Blizard Institute, Barts and The London School of Medicine and Dentistry, Queen Mary University of London, 58 Turner Street, London E1 2AB UK.

To cite: Epstein M. Living kidney donation and masked nationalism in Israel Indian J Med Ethics. Published online on December 13, 2016.

(c) Indian Journal of Medical Ethics 2016
Sectarian donation, which is the focus of this article, may under certain circumstances seem moral, or at least not immoral. For example, donation that is directed specifically to children or to a social group that happens to have relatively poor access to organs may arguably be moral. By contrast, donation that actually or even just ostensibly involves racism, nationalism, chauvinism or bigotry of some sort is probably, not to say evidently, immoral, though some scholars would not reject it on this ground alone. They argue that even divisive donations save lives, saving lives being the highest value (4-6).

In any case, putting aside subjective moral sentiments, sectarian donation is almost invariably in breach of the prevailing international transplant ethic. In other words, the current codes happen to consider it immoral and unacceptable regardless of the nature of the conditions laid down by the donors. Exceptions are rare and, at any rate, tangential to solid organ donation. For example, the Australian Assisted Reproductive Technology Act 2007 (New South Wales) explicitly permits gamete donors to discriminate against potential recipients on any basis, including race, ethnicity and sexual preference (7).

It is likely that most transplant systems would reject deceased or living organ donations if the donors were to be plain about their sectarian motives. The ethical positions of national systems may not always be set forth in detail, but there is no doubt as to their anti-sectarian spirit.

In 1998, the next-of-kin of a deceased British white man specified that his organs could not be allocated to non-whites. The organs were accepted and allocated to white people who, by coincidence, would have been the recipients anyway. However, following criticism in the British media, a Department of Health investigation concluded, among other things, that that "racist conditions are completely abhorrent" and should be prohibited $(8,9)$.

The National Health Service (NHS) Blood and Transplant policy is even wider: "It is a fundamental principle of the UK donation programme that organs are freely and unconditionally given."(10).

The Transplantation Society (TTS) takes a similar position and so does the US United Network for Organ Sharing (UNOS). According to the former, "...[conditions] imposed on the selection of recipients interfere with the principles of justice and equity, and sometimes also the principle of utility. In this situation, the rights of the recipients based on these ethical principles overrule the donor's right to autonomy. Despite the 
organ shortage, the offer for donation should, therefore, be declined."(11).

Elaborating on the ethical principles in organ donation, the UNOS states: "UNOS has long opposed donations directed to a social group (based on race, religion, gender, or sexual orientation)."(12).

In view of this global ethical stance, one may assume that sectarian donations can take place only if they conceal themselves behind some ethical guise.

This paper draws attention to a current trend of masked sectarian living kidney donation in Israel, to which the local transplant system has been turning a blind eye. The paper seeks to make the international transplant and bioethics communities aware of this trend and the way it conceals itself. It also explains why it is wrong and suggests how to tackle it. Finally, it calls on the Israeli system to bring the practice to a halt for the benefit of all parties involved.

\section{The Israeli case}

The 2008 Declaration of Istanbul on Organ Trafficking and Transplant Tourism marked the launch of a concerted international campaign against these disturbing practices (1). As part of this campaign, one article drew attention to the hitherto ignored potential of altruistic, directed, individualto-individual living unrelated donation (LURD), which is, in principle, ethically acceptable and widely encouraged, to conceal commerce in organs(13). The risk still exists. Most transplant programmes require a detailed psychological evaluation to assess the donor's capacity to make an informed and free decision, and to rule out commerce (14). However, the tests remain weak for two reasons. First, monetary transaction is difficult to identify as both donor and recipient are usually coached to deceive the system of oversight. Second, and perhaps more crucially, the transplant system fears that more rigorous tests would be likely to diminish the number of acceptable donations (15).

There is, however, another hazard associated with altruistic individual-to-individual LURD that has so far received no attention at all: the risk that it conceals a sectarian condition.

The Israeli media have recently reported an increasingly popular trend of conditional living kidney donation from Jews to Jews, disguised as altruistic, directed individual-toindividual LURD. It is definitely a trend, and not some isolated cases. Taking place between total strangers, the donations are brokered by a Haredi charity, called Matnat Chaim (Gift of Life) - Volunteers for Kidney Transplantation, which matches donors and recipients. It has recorded more than 331 donations since 2009, against a waiting list of 850(1618). The trend now seems to involve other countries as well. The charity reports that on May 18, 2016, the London-based Royal Free Hospital performed a transplant involving an Israeli donor and a British recipient, who had been "brought together" under the auspices of the charity $(19,20)$.
The chairman of Matnat Chaim, rabbi Yeshayahu Haber, regards this trend as wonderfully unique: "This is the only country in the world with so many people donating their kidneys voluntarily to strangers"(in the following, all translations from Hebrew are mine, M.E.)(18). Haber also reveals the motivation: "Most donors wish to 'save a Jewish soul'; thus most recipients are Jews."(21). Interviewing a group of volunteers of the charity, one reporter writes:

Would you be willing to donate a kidney to a nonJew as well? They find the question difficult to answer. Rabbi Shapira volunteers to answer on their behalf: “One person says, 'I am willing to donate a kidney to my brother, or even to my cousin, but not to my neighbour. I am saying I am willing to donate to my brother, and also to my cousin, and also to the cousin of the cousin, and also to my people in general. Thus my family includes my people. I have no problem donating to an Arab ... but on condition that someone from his family donate a kidney to a Jew. I am willing to put myself at risk so that eventually my extended family - that is, my people - will live; I don't mind if this is achieved directly or indirectly."(17).

\section{Another reporter notes:}

But if everything so far has seemed philanthropic, pure and altruistic, we now arrive at the most controversial point about Matnat Chaim: the charity allows the donors to direct their donation to recipients of some specific kind. They can choose the sex of the recipient; they can choose their age; and they can choose their nationality. So far, all donors have made one condition: the recipient must be a Jew (22).

What is more, the Israeli transplant community and its system of oversight have been collaborating to keep this sectarian trend alive, turning a blind eye to the fictitious nature of its ethical guise. Paulina Katz, a transplant coordinator in a major Tel Aviv hospital, says, "Those who donate through the National Transplant Center may not decide who will receive their kidney. The charity, which connects donor and recipient, is in fact a bypass. ... They come to us as a couple, and we do not intervene in the matching process."(21).

Professor Eytan Mor, one of Israel's most senior transplant surgeons, adds, "Honestly, I avoid talking about this phenomenon in international conferences. I know we will be criticized."

Interestingly, it is not the sectarian-unethical nature of the practice that he seeks to hide from potential critics. Apparently, it is well hidden from him, too. Rather, he wishes to avoid accusations that "the donation reflects not free will, but rabbinical pressures" (17). Such pressures exist, so he seems to suggest, but they do not trouble him too much either.

\section{A clarification}

The trend in question is evidently sectarian. However, it is important to note that it is driven neither by religion, nor by 
any special needs of the population of Jewish patients. Rather, it is nationalist, as the following points indicate, and this makes it particularly disturbing.

First, while the Halacha - the Jewish orthodox law and jurisprudence - forbids deceased organ donation, it has no principled objection to living organ donation. Nor does it place any conditions, whether religious, national or other, on such donation. It does not prohibit donation to a Gentile, then. Nor does it prioritise Jewish recipients.

Second, with respect to the disturbing trend in question, the recipients are Jews, but not necessarily orthodox or even religious.

Third, as far as living donations are concerned, the Jewish patients on the waiting list do not form an underprivileged group.

Finally, while the vast majority of donors consists of orthodox Jews, many of them happen to be ultra-nationalist West Bank settlers. The fact that many are "repenters"- people who embraced the religious faith only recently - may partially explain their susceptibility to rabbinical pressures to donate an organ. However, it does not explain their preference for donating an organ to a Jew and only to a Jew. Their nationalism does. This paper focuses on the problem with this particular motivation. Issues pertaining to the donors' vulnerability and the possibility of undue influence warrant a separate discussion.

\section{What is wrong with conditional-nationalist donation?}

The complicity of the Israeli transplant system with this conditional-nationalist trend is undisputedly unethical (masking it behind an ethical cloak makes things even worse). But is it also morally unjustifiable? Moreover, is the trend itself morally unjustifiable?

It is not easy to be sure about the answer. The charity could argue that notwithstanding its silent nationalist ideology, it is not directly exclusionist; thus it should not be perceived as offensive by those whom it does not serve, notably, the Israeli Palestinian population. The charity could even say to this population, "Look, we take care of our people. This is normal. Everybody does it. Why don't you do it too? In fact, we would be more than happy to share our experience with you and help you set up a similar charity for your own people." The charity could also argue that, in fact, it benefits the Palestinians as well. By removing Jewish patients from the waiting list, it effectively shortens it. Regardless of the points made earlier, the donors, the charity and the complicit transplant system could argue that they all save lives, and saving life overrides any objection one may raise.

These arguments may sound convincing. The question is whether they are relevant. I wish to argue in brief that they are not, given the current Israeli political and medical contexts.

Israeli Palestinians, who number more than 1.7 million and constitute about $20 \%$ of the total population, are effectively treated and certainly feel that they are treated as second-class citizens. Israel fosters these feelings. For example, it explicitly regards itself as a Jewish state, not a state of and for all its citizens. It discriminates against the Israeli Palestinians in the matters of public funding, social integration, economic status and mobility. It hardly ever allows them to unite with their nonIsraeli family, unless they are willing to emigrate. Kibbutzim would not accept Palestinian members. A policy of Jewification of areas densely populated by Palestinian citizens has been followed for decades. Senior politicians and others are calling for the transfer of the Palestinian population or parts of it. Attempts to ostracise Palestinian MPs are also increasing. Even the mere idea of a coalition government with their parties is deemed national betrayal. During the last general elections, the Israeli Prime Minister warned the Jewish voters, "The Arabs are moving in droves to the polling stations."(23) This deeply disturbing bias is all-pervasive. It affects the Israeli healthcare system as well. It has recently been reported that some hospitals separate Jewish and Palestinian women in maternity wards upon the request of the former (24). Many regard what is currently going on in Israel as some form of apartheid. Recently, the Israeli army's deputy chief of staff suggested a parallel between present-day Israel and the Germany of the 1930s (25). The continuing occupation in the West Bank and the siege on the Gaza Strip, which affect millions of non-Israeli Palestinians, are another matter.

Against this backdrop, a Jewish-sectarian donor-recipient matching programme cannot be perceived as anything but a segregationist, exclusionist enterprise. The Israeli transplant system's pseudo-ethical complicity with the programme thus becomes particularly disturbing. Instead of bringing peoples together, the imperative of the hour, this complicity helps to tear them apart. While saving the lives of the few, it mirrors the murky political stream that threatens the lives of the many. If only for these reasons, it is necessary to bring an end to this complicity.

\section{What is to be done?}

In our troubled world, the risk of altruistic individual-toindividual LURD concealing sectarian (and, of course, commercial) donations is likely to rise. Perhaps it may not be avoided completely. However, the international transplant community can reduce it significantly by embracing the default fictitious-but-realistic assumption that something is bound to be wrong with unrelated donations that are directed to recipients identified through the Internet (eg matchingdonors.com), or through third-party organisations (eg Matnat Chaim). The system must reject such offers without exception, regardless of how convincing the explicit motives of the donor may sound and irrespective of how close the donorrecipient relationship may seem.

\section{Conclusion}

With all respect to patients on waiting lists and their caring doctors, some forms of kidney donation are utterly unacceptable: "donations" from vendors, "donations" from 
executed prisoners, and also conditional-divisive donations. The Israeli nationalist trend and the complicity of the local and other systems therewith must stop at once. Israel has done a lot in recent years to combat organ trafficking and transplant tourism, phenomena that were once pervasive in the country. It does not need another scandal to undermine its commendable achievements. Nor does its deeply divided society need it. Nor do Jews worldwide need it. Sectarianism and exclusion have caused them enough suffering.

\section{References}

1. The Declaration of Istanbul on Organ Trafficking and Transplant Tourism [Internet] [cited 2016 Oct 6].Available from:http://www. declarationofistanbul.org/about-the-declaration/structure-andcontent

2. Lavee J, Ashkenazi T, Gurman G, Steinberg D. A new law for allocation of donor organs in Israel. Lancet. 2010;375(9720):1131-3.

3. Veatch RM, Ross LF (eds).Transplantation Ethics, Second Edition. Washington, DC: Georgetown University Press; 2015, p 393-5.

4. Moorlock G, Ives J, Bramhall S, Draper H. Should we reject donated organs or permit allocation using non-medical criteria? A qualitative study. Bioethics. 2016;30(4):282-92.doi: 10.1111/bioe.12169.

5. Cronin AJ, Douglas JF. Directed and conditional deceased organ donations: laws and misconceptions. Med Law Rev. 2010;18(3):275-301.

6. Wilkinson TM. Racist organ donors and saving lives. Bioethics. 2007;21(2):63-74.

7. Komesaroff PA, Kerridge IH, Stewart C, Samuel G, Lipworth W, Jordens CF. Racially conditional donation: the example of umbilical cord blood. $J$ Law Med. 2012;19(3):517-24.

8. Racist organ donation condemned. BBC News 24 Feb 2000[Internet] [cited 2016 Oct 6]. Available from:http://news.bbc.co.uk/1/hi/ health/652132.stm

9. Department of Health, UK. Report of the Panel. An Investigation into Conditional Organ Donation, 2000.

10. NHS Blood and Transplant. POL200/3. 2010. Requested Allocation of a Deceased Donor Organ;[Internet] [cited 2016 Oct 6]. Available from: http://www.odt.nhs.uk/pdf/introduction_to_selection_and_ allocation_policies.pdf

11. Tibell A. The Transplantation Society statement on directed and conditional donation. Transplantation. 2008;85(11):1538-9.doi:10.1097/ TP.0b013e318172db18.

12. United Network for Organ Sharing (UNOS) Ethics Committee. Ethical Principles in the Allocation of Human Organs,IV(B);2010 [Internet] [cited 2016 Oct 6]. Available from: https://optn.transplant.hrsa.gov/resources/ ethics/ethical-principles-in-the-allocation-of-human-organs/

13. Epstein M, Danovitch GM. Is altruistic directed living unrelated organ donation a legal fiction? Nephrol Dial Transplant. 2009;24(2):357-60. doi: 10.1093/ndt/gfn669.

14. Dew MA, Jacobs CL, Jowsey SG, Hanto R, Miller C, Delmonico FL; United Network for Organ Sharing (UNOS); American Society of Transplant Surgeons; American Society of Transplantation. Guidelines for the psychosocial evaluation of living unrelated kidney donors in the United States. Am J Transplant. 2007;7(5):1047-54.

15. Pegg A, Klein $A$. The ethics of living donation. In: Kirk AD, Knechtle SJ, Larsen CP, et al, editors. Textbook of Organ Transplantation. Oxford, Chichester, Hoboken, NJ:Wiley-Blackwell; 2014, p 1656.

16. Kellner Y. High kidney morals. Yediot Achronot [Internet]. 2015 Apr 1 [cited 2016 Oct 6]. Hebrew. Available from: http://article.yedioth.co.il/ default.aspx?articleid $=9261$

17. Ehrlich Y. Moral kidney donors. Yediot Achronot [Internet]2016 Apr 28 [cited 2016 Oct 6]. Hebrew. Available from: http://www.yediot.co.il/ articles/0,7340,L-4796824,00.html

18. Elizera R. Following his brother: Elyashiv donated a kidney to a man he had not known. Yediot Achronot [Internet]. 2016 Aug 22 [cited 2016 Oct 6]. Hebrew. Available from: http://www.ynet.co.il/ articles/0,7340,L-4844577,00.html

19. Matnat Chaim - Volunteers for Kidney Transplantation [Internet] [cited 2016 Oct 6]. Available from: http://www.kilya.org.il/en/

20. Matnat Chaim - Kidney Transplantation [Internet]. 2016 May 18 [cited 2016 Oct 6]. Hebrew. Available from: https://www.facebook.com/ matnatchaim/?fref=ts

21. Lanski N. Surprise kidney. Israel Hayom [Internet]2015 Jan 30 [cited 2016 Oct 6]. Hebrew. Available from: http://www.israelhayom.co.il/ article/254149

22. Pevsner Bashan Y. How did rabbi Haber convince 311 Israelis to donate a kidney? Mako [Internet]. 2016 Jun 23 [cited 2016 Oct 6]. Hebrew. Available from: http://www.mako.co.il/health-weekend/Articlecc39d4f42677551006.htm?sCh=7d61bdd9ccbc4310\&pld=1471243973 \&Partner $=\mathrm{mw}$

23. Lynfield B. Israel election: Benjamin Netanyahu claims shock victory despite ugly racism row overshadowing final acts of bitter campaign. Independent [Internet] 2015 Mar 17[cited 2016 Oct 6]. Available from:http://www.independent.co.uk/news/world/middle-east/israelelection-benjamin-netanyahu-fights-for-survival-as-ugly-racism-rowovershadows-final-acts-of-10114922.html

24. Siegel-Itzkovitch J, Ben Solomon A. Smotrich supports hospital room segregation between Jews and Arabs. The Jerusalem Post [Internet] 2016 May 4 [cited 2016 Oct 6]. Available from:http://www.jpost.com/IsraelNews/Report-Various-Israeli-hospitals-separate-pregnant-Jewish-Arabon-request-450271

25. IDF general in bombshell speech: Israel today shows signs of 1930 s Germany. The Jerusalem Post [Internet]. 2016 Apr 5 [cited 2016 Oct 6]. Available from:http://www.jpost.com/Israel-News/Politics-AndDiplomacy/IDF-general-in-bombshell-speech-Israel-today-showssigns-of-1930s-Germany-453142 